\title{
Ecological Assessment of Heavy Metals in Sediments from Jianhu Lake in Yunnan Province, China
}

\author{
Bo Li ${ }^{1,2,3}$, Hang Wang ${ }^{1,2}$, Qingguo Yu' ${ }^{1,2 *}$, Feng Wei ${ }^{4}$, Qi Zhang \\ ${ }^{1}$ College of Wetlands, Southwest Forestry University, Kunming Yunnan, China \\ ${ }^{2}$ National Plateau Wetlands Research Center, Kunming Yunnan, China \\ ${ }^{3}$ Institute of Environmental and Ecological Engineering, Guangdong University of Technology, \\ Guangzhou Guangdong, China \\ ${ }^{4}$ College of Ecology and the Environment, Southwest Forestry University, Kunming Yunnan, China \\ ${ }^{5}$ College of Eco-Environmental Engineering, Guizhou Minzu University, Guiyang Guizhou, China
}

Received: 4 September 2019

Accepted: 14 February 2020

\begin{abstract}
Cadmium $(\mathrm{Cd})$, chromium $(\mathrm{Cr})$, copper $(\mathrm{Cu})$, lead $(\mathrm{Pb})$ and zinc $(\mathrm{Zn})$ in the sediments of Jianhu Lake were measured by an inductively coupled plasma-optical emission spectrometer (ICP-OES) to determine their spatial distribution characteristics and ecological risks. The results showed that the average concentrations of $\mathrm{Cd}, \mathrm{Cr}, \mathrm{Cu}, \mathrm{Pb}$ and $\mathrm{Zn}$ in surface sediments $(0-5 \mathrm{~cm})$ were $0.41 \pm 0.34$, $143.89 \pm 90.07,46.14 \pm 30.08,56.38 \pm 45.71$, and $146.52 \pm 96.50 \mathrm{mg} / \mathrm{kg}$, while those in core sediments $(0-75 \mathrm{~cm})$ were $0.51 \pm 0.44,228.35 \pm 174.52,89.94 \pm 74.63,74.92 \pm 65.69$, and $208.89 \pm 171.55 \mathrm{mg} / \mathrm{kg}$, respectively. The total concentrations of heavy metals were highest in the western area of Jianhu Lake, and were higher in the bottom layer $(70-75 \mathrm{~cm})$ than in the surface layer $(0-5 \mathrm{~cm})$ in the entire Jianhu Lake region. The potential ecological risks of $\mathrm{Cd}$ in sediments were greatest, and the comprehensive potential ecological risks of the five tested heavy metals in sediments were highest in the western area of Jianhu Lake. Using the geoaccumulation index $\left(I_{\text {geo }}\right)$, we found that pollution in sediments due to $\mathrm{Cr}$ was the most serious of all the heavy metals, and the degree of pollution due to these five heavy metals in each area varied greatly in Jianhu Lake. In addition, we found that the short-term release contribution of $\mathrm{Pb}$ and $\mathrm{Zn}$ was large, while both the short- and long-term release contributions of $\mathrm{Cr}$ were small.
\end{abstract}

Keywords: sediment, heavy metal, spatial distribution, ecological assessment, release contribution 


\section{Introduction}

Northwest Yunnan Province is located in the transitional zone from the Qinghai-Tibet Plateau to the Yunnan-Guizhou Plateau. It is in the world-famous Three Parallel Rivers Region. This special natural environment has a rich biodiversity. It is not only one of the 25 "hot spots" of biodiversity in the world [1], but is also the first zone of 17 key biodiversity preferential conservation areas in China [2]. The group of lakes in northwest Yunnan Province plays an important role in the conservation of biodiversity and the maintenance of water ecological security in the Three Parallel Rivers Region, and thus it has high value in conservation and research. Sediments are an integral component of an aquatic ecosystem and provide habitat, feeding, spawning and rearing areas for many aquatic organisms [3-4]. However, they are also important carriers of heavy metals in aquatic ecosystems [5]. In recent years, studies on lake sediments in northwest Yunnan Province have shown that heavy metal pollution in sediments is serious, such as in the Napaihai wetland [6] and Chenghai Lake [7]. In addition, the concentration of heavy metals in sediments from plateau lakes in China has increased year by year [8]. Heavy metals are one of the most worrying pollutants in our natural environments due to their toxicity, persistence and bioaccumulation [9]. Direct toxicity to human and aquatic life and indirect toxicity through the accumulation of metals in aquatic food chains are a focus of scientific research [10].

In recent years, research on heavy metals in lake sediments of Yunnan Plateau in China has focused mainly on such lakes as Dianchi [11], Chenghai [7], and Yangzonghai [12] and so on, and less attention has been was paid to Jianhu, which is one of the group of lakes in northwest Yunnan Province, China. Jianhu is a wellpreserved plateau lake wetland in northwestern Yunnan Province. It is a typical plateau erosional lake and is one of the types of small plateau shallow lake wetlands in China. Therefore, if there is heavy metal contamination in the sediments of Jianhu Lake, it is more difficult for the lake to recover compared with lakes in other regions [13]. Furthermore, most of the plateau lakes are in a relatively closed geographical environment [14]. Thus, the oxidation-reduction environment in plateau lakes is unique, and the accumulation and release of heavy metals in sediments are also different from lakes in other districts.

Surface sediments are often exchanged with suspended matter in water and reflect current environmental conditions [5], while bottom sediments have a relatively stable history of human and natural processes [15]. Meanwhile, the assessments of heavy metal pollution and ecological risk in sediments are of prime importance to improve management and prevention strategies and have been taken into serious consideration [16-17]. In order to comprehensively evaluate the current heavy metal pollution status and ecological risk in the sediments of Jianhu and determine the process of heavy metal deposition, sediments were collected from the lake. Research on the release contribution of heavy metals in vertical profile is rarely performed. In the present study, based on the release contribution of phosphorus in core sediments [18], the release contribution of heavy metals in sediments from Jianhu Lake was analyzed. In general, heavy metals such as cadmium $(\mathrm{Cd})$, chromium $(\mathrm{Cr})$, copper $(\mathrm{Cu})$, lead $(\mathrm{Pb})$ and zinc $(\mathrm{Zn})$ can threaten the health of entire ecosystems in addition to humans [19-21]. The purpose of determining $\mathrm{Cd}, \mathrm{Cr}, \mathrm{Cu}, \mathrm{Pb}$ and $\mathrm{Zn}$ was to reveal the horizontal and vertical spatial distribution characteristics, ecological risks, pollution levels and release contributions of these heavy metals in the sediments from Jianhu. The results may also provide a base for the prevention and control of heavy metal pollution in the sediments of Jianhu Lake.

\section{Materials and Methods}

\section{Study Area}

Jianhu Lake, located in Jianchuan County, Dali Bai Nationality Autonomous Prefecture, Yunnan Province, China, is part of the Mekong River (called the Lancang River in China) Basin. The Jianhu Basin covers a large area of approximately $883 \mathrm{~km}^{2}$, and the pollution sources in the basin are extensive, while Jianhu Lake is only about $6 \mathrm{~km}^{2}$. There are rivers, such as the Yongfeng, Jinlong and Gemei (Fig. 1) near Jianhu Lake, and the water in Jianhu flows from the Haiwei River. There are many rivers around Jianhu, but only one river out of the lake. Therefore, the water retention period is relatively long due to the closed geographical environment. There are some potential sources of heavy metal contamination in Jianhu Lake Basin, such as a lead-zinc heap, municipal and domestic sewage and garbage, wood carving industries and so on. Jianhu was listed as a provincial wetland nature reserve by the government in 2006 and is located in the wetland ecological natural preservation zone. It was listed as the first batch of provincial-level important wetlands by the government in 2016. The lake is not only a gathering point and a stopping place for migratory birds, but also a wintering habitat for migratory waterfowl, and it is also an important area for biodiversity conservation in northwest Yunnan Province, China.

\section{Sediment Collection}

Sediments were sampled according to the shape of Jianhu Lake, conditions of the rivers, human disturbance, and industrial and agricultural distribution in June 2017; 12 sampling points in total were established marked as 1 to 12 (Fig. 1). In order to restore Jianhu Lake and expand the lake area, the Yunnan Jianhu Wetland Provincial Nature Reserve Administration implemented 


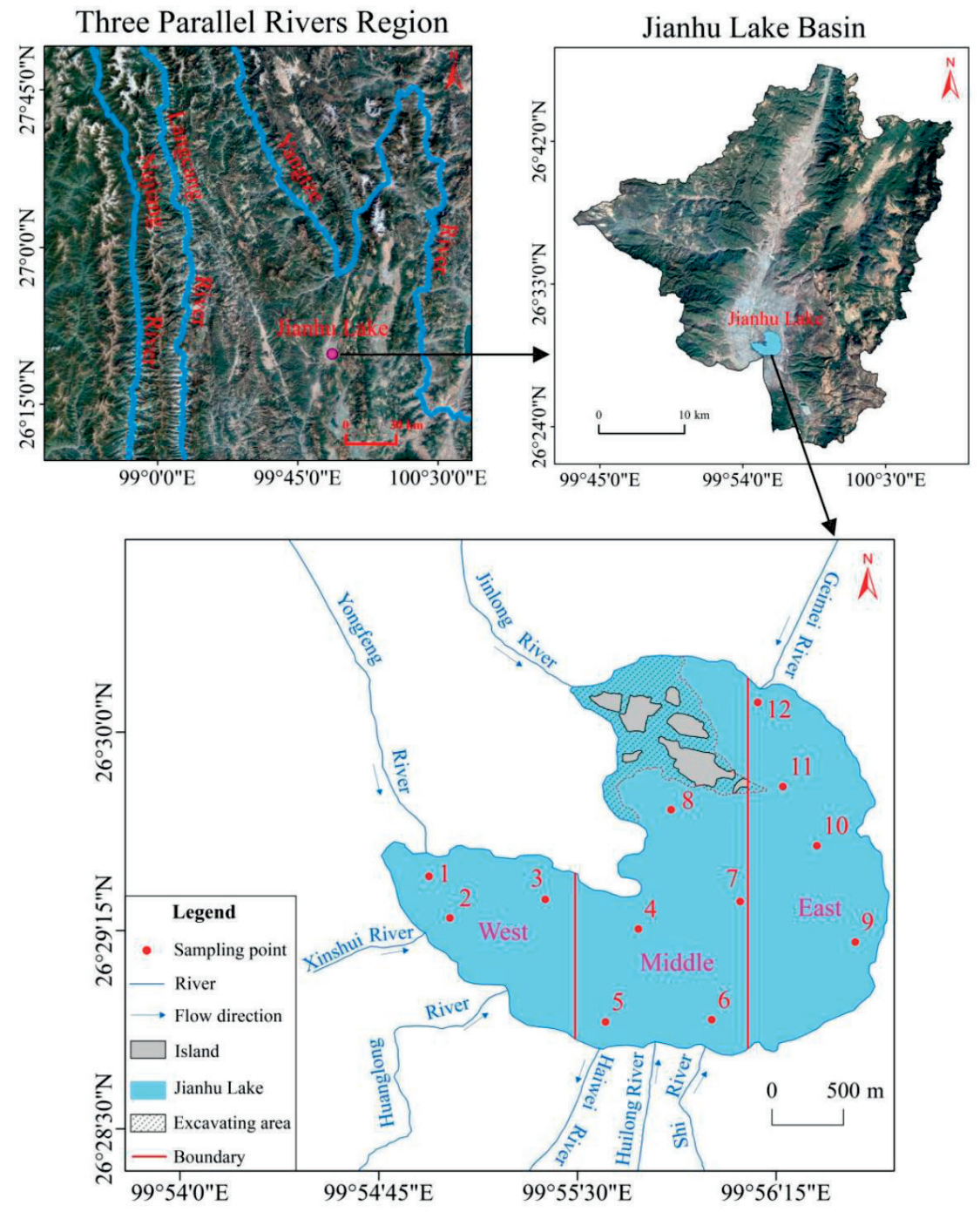

Fig. 1. Distribution of sediment sampling points in Jianhu Lake.

a dredging project in the Jinlong River estuary in the first half of 2016, which resulted in a large disturbance to the sediments; thus, sediments in this area were not collected. All sediment samples were collected using a deep-hole drill (Eijkelkamp 0423SA, Netherlands). A core sediment sample $(0-75 \mathrm{~cm})$ was taken at each sampling point and divided into 15 layers from top to bottom ( $5 \mathrm{~cm}$ per layer). There were 180 samples in total, and all sediment samples were placed in clean plastic zip-lock bags, transferred to an icebox and then transported to the laboratory for further processing within one week.

\section{Laboratory Analytical Methods}

The samples were dried, passed through a 100 -mesh nylon sieve for easy digestion until the sediment residue disappeared and the solution turned into white or light yellow, sealed to avoid contamination, and then stored at room temperature until analysis. For heavy metal testing, $0.2000 \mathrm{~g}$ of sediment sample was weighed accurately and $8 \mathrm{ml} \mathrm{HNO}_{3}, 8 \mathrm{ml} \mathrm{HCl}$, and $10 \mathrm{ml} \mathrm{HF}$ were added to a screw-top polytetrafluoroethylene high-pressure microwave digestion tank. The samples were dissolved in the microwave digestion instrument for $70 \mathrm{~min}$, and then heated to near dryness with a constant temperature digestion instrument. After shaking for $20 \mathrm{~min}$ with an ultrasonic cleaner, the liquor was adjusted to $50 \mathrm{ml}$ with $1 \% \mathrm{HNO}_{3}$, and then the content of heavy metals was measured by an inductively coupled plasma-optical emission spectrometer (ICPE-9820, Japan). In this study, 10\% of samples were selected randomly for three repeated experiments due to the large number of samples, and one blank sample was analyzed to correct for contamination during the experimental process. A Chinese Standard Substance (GBW 07309) was included for quality control. The results showed that the coefficient of variation of all replicates of each tested sample and the coefficient of variation of standard substances were less than $10 \%$. In order to confirm the accuracy of our measurements, $5 \%$ of sample solutions were randomly selected for three repeated measurements during the testing process. The repeated measurement results showed that the 
coefficient of variation was less than $5 \%$, indicating that the stability of the instrument was high and the results met the requirements.

\section{Pollution and Ecological Risk Assessment}

Common methods for evaluating heavy metals in sediments include the potential ecological risk index [17], geoaccumulation index [15], sediment quality guidelines [22], enrichment factor [5], and the sediment pollution load index [23]. These methods have different characteristics and scope of application, and they also have their own limitations in practical applications, but the geoaccumulation index and potential ecological risk index are currently the most commonly used methods [24].

The geoaccumulation index $\left(I_{\text {geo }}\right)$ is a quantitative indicator proposed by Müller [25]. This method evaluates whether sediments are contaminated by heavy metals and effectively indicates the environmental quality of sediments [15]. Additionally, human disturbance factors and geochemical background are considered in this method; therefore, it can objectively evaluate the degree of heavy metal pollution in sediments, and the obtained values mainly represent the influence of human activities in the process of heavy metal enrichment. This index is calculated as follows:

$$
I_{\text {geo }}=\log _{2}\left(\frac{C_{n}}{1.5 \times B_{n}}\right)
$$

...where $C_{n}$ is the concentration of metal $n$ in sediments, $B_{n}$ is the background concentration value for metal $n$, and factor 1.5 is used because of possible variations in the background data due to lithological variations [26]. In this study, the arithmetic mean content of soil elements in the A layer $(0-20 \mathrm{~cm})$ of Yunnan Province was used as the background concentration value $(\mathrm{Cd}=0.218, \mathrm{Cr}=65.2, \mathrm{Cu}=46.3, \mathrm{~Pb}=40.6$, $\mathrm{Zn}=89.7 \mathrm{mg} / \mathrm{kg}$ ) in the evaluation process, and the range values of $\mathrm{Cd}, \mathrm{Cr}, \mathrm{Cu}, \mathrm{Pb}$ and $\mathrm{Zn}$ are 0.009-3.409, $13.7-126.0,6.2-208.9,9.5-490.0$ and $14.0-281.0 \mathrm{mg} / \mathrm{kg}$ $(\mathrm{n}=73)$, respectively [27], and to reflect the degree of pollution in contrast to the local background data [17]. According to the values of $I_{g e o}$, the degree of heavy metal pollution in sediments can be graded, and the classification criteria are shown in Table 1 [28].

The potential ecological risk index (RI) was introduced by Hakanson from the perspective of sedimentology to evaluate the ecological risk of heavy metals in sediments [29]. The toxicity of heavy metals and the difference in regional background values are considered in this method. The index can be calculated as follows:

$$
\mathrm{RI}=\sum_{i=1}^{m} E_{r}^{i}, \text { where } E_{r}^{i}=T_{r}^{i} \times \frac{C^{i}}{C_{n}^{i}}
$$

... where $E_{r}^{i}$ is the potential ecological risk index of single element $i$ in sediments, and $m$ is the amount of heavy metal elements. $T_{r}^{i}$ is the toxicity response coefficient of element $i$, where $T_{r}^{i}$ for $\mathrm{Cd}, \mathrm{Cr}, \mathrm{Cu}, \mathrm{Pb}$ and $\mathrm{Zn}$ are 30, 2, 5, 5 and 1, respectively [29]. $C^{i}$ is the measured concentration of heavy metal $i$ and $C^{i}$ is the reference value of heavy metal $i$ collected from the natural geochemical background concentration of heavy metals in the A soil layer $(0-20 \mathrm{~cm})$ in Yunnan province [27]. The classifications of RI and $E_{r}^{i}$ are related to the type and quantity of pollution, and this study only includes five heavy metals (which is different than the eight types of pollution studied by Hakanson) [29]. Therefore, the classification criteria were adjusted according to the methods by Hou Qian et al. [30]. The standard is shown in Table 2.

\section{Release Contribution}

Sediments can adsorb heavy metals in water and in turn reduce the level of water pollution. However, the pollutants can be released from the sediments when environmental conditions such as magnetic properties, particle size, organic carbon, total nitrogen, and total phosphorus change in the sediments, and can cause secondary pollution in the water environment [31-32]. Therefore, it is necessary to study the release of heavy metals in sediments.

Heavy metals would be released and distributed again and produce secondary pollution due to the change of hydrodynamic conditions and the influence of biological activities [33]. Huang et al. have justified that the heavy metals in bottom sediments can be released to surface environment and diffused in vertical profile [34]. According to the first law of Fick regarding steady-state diffusion, the diffusion flux of materials in vertical space is proportional to the concentration in the area [35]. In addition, the migration of elements has continuity in time and space. This means that the migration and release of heavy metals in core sediments depend on the concentration between the two adjacent layers. In this study, based on the release contribution of

Table 1. Geoaccumulation index and classification of degree of pollution.

\begin{tabular}{|c|c|c|c|c|c|c|c|}
\hline Grade & I & II & III & IV & V & VI & VII \\
\hline$I_{\text {geo }}$ & $\leq 0$ & $0-1$ & $1-2$ & $2-3$ & $3-4$ & $4-5$ & $>5$ \\
\hline Pollution degree & Clean & Low & Very slight & Slight & Moderate & High & Very high \\
\hline
\end{tabular}


Table 2. Grading standard of potential ecological risk evaluation.

\begin{tabular}{|c|c|c|c|c|c|}
\hline Grade & I & II & III & IV & V \\
\hline$E_{r}{ }^{i}$ & $E_{r}{ }^{i}<30$ & $30 \leq E_{r}^{i}<60$ & $60 \leq E_{r}^{i}<120$ & $120 \leq E_{r}^{i}<240$ & $E_{r}^{i} \geq 240$ \\
\hline RI & $\mathrm{RI}<40$ & $40 \leq \mathrm{RI}<80$ & $80 \leq \mathrm{RI}<160$ & $\mathrm{RI} \geq 160$ & \\
\hline Risk status & Low & Moderate & High & Very high & Extremely \\
\hline
\end{tabular}

phosphorus in core sediments, the release contribution of heavy metals in sediments was divided into two types: short-term release contribution $\left(V_{1}\right)$ and longterm release contribution $\left(V_{2}\right)$ [18]. Release contribution can be calculated as follows:

$$
V_{1}=\frac{\left(k_{1}-k_{2}\right)}{\sum_{i=1}^{n}\left|k_{1}-k_{2}\right|} \times 100 \% \quad V_{2}=\frac{\left(k_{1}-k_{3}\right)}{\sum_{i=1}^{n}\left|k_{1}-k_{3}\right|} \times 100 \%
$$

...where $n$ is the number of heavy metal elements in sediments, and $k_{1}, k_{2}$ and $k_{3}$ are the average content of heavy metal elements in sediments from the first layer $(0-5 \mathrm{~cm})$, the second layer $(5-10 \mathrm{~cm})$ and the bottom layer $(70-75 \mathrm{~cm})$, respectively. Generally speaking, the value is positive, indicating that this heavy metal element has the potential for release; negative values indicate that this heavy metal element has the potential for retention.

\section{Results}

\section{Heavy Metal Concentrations in Surface Sediments}

The contents of $\mathrm{Cd}, \mathrm{Cr}, \mathrm{Cu}, \mathrm{Pb}$ and $\mathrm{Zn}$ in the surface sediments $(0-5 \mathrm{~cm})$ of Jianhu Lake were $0.412 \pm 0.341$,
$144 \pm 90.1,46.1 \pm 30.1,56.4 \pm 45.7$ and $147 \pm 96.5 \mathrm{mg} / \mathrm{kg}$, respectively. The spatial distribution is illustrated in Fig. 2. The average heavy metal concentrations in the surface sediments of Jianhu Lake, with the exception of $\mathrm{Cr}$, showed the order west $>$ middle $>$ east, while $\mathrm{Cr}$ showed the order of middle $>$ west $>$ east. In addition, the concentration of these five heavy metals was relatively high in the vicinity of the Xinshui River estuary and low at the entrance to the Gemei River and excavation area of Jianhu Lake, and the concentrations of $\mathrm{Cd}$ and $\mathrm{Pb}$ were high in some areas of the eastern section. In addition, to facilitate the evaluation and comparison, the average concentrations of national aquatic sediments and south aquatic sediments in China are also shown in Table 3. It can be seen from Table 3 that the average values of heavy metals in the surface sediments of Jianhu were all higher than the average concentrations in national aquatic sediments and south aquatic sediments in China. The contents of $\mathrm{Cd}$ and $\mathrm{Cr}$ in sediments from the lake were 1.83 times and 2.53 times that of the average concentration in national aquatic sediments. The concentrations of $\mathrm{Cd}, \mathrm{Cr}$ and $\mathrm{Zn}$ in sediments from Jianhu were 1.51, 2.37, and 1.39 times the soil background value in Yunnan Province, respectively, while the concentrations of $\mathrm{Cu}$ and $\mathrm{Pb}$ were close to the soil background value in Yunnan Province.
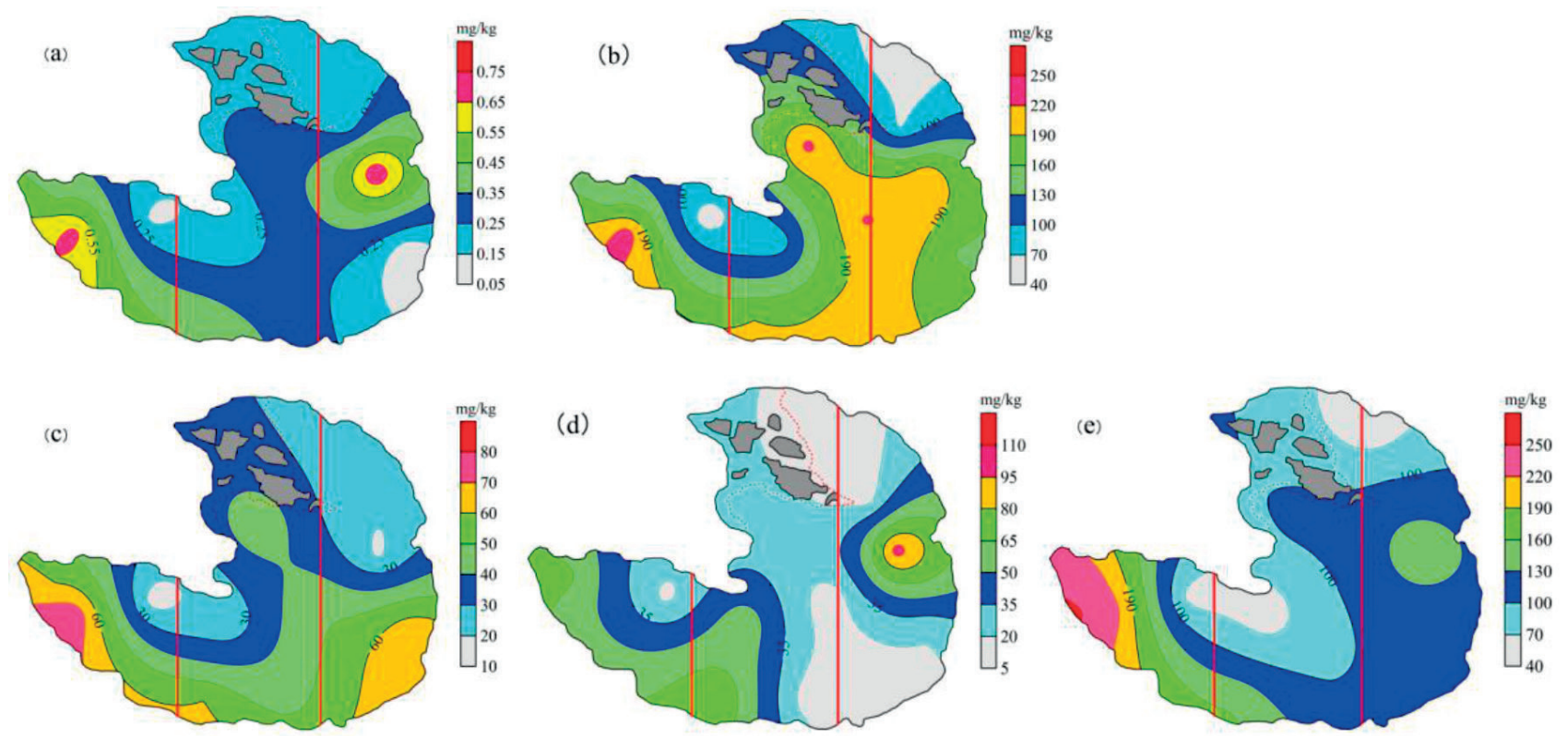

Fig. 2. Horizontal distributions of $\mathrm{Cd} \mathrm{a}$ ), $\mathrm{Cr}$ b), $\mathrm{Cu}$ c), $\mathrm{Pb} \mathrm{d}$ ) and $\mathrm{Zn}$ e) in Jianhu Lake surface sediments. 
Table 3. Average concentrations of $\mathrm{Cd}, \mathrm{Cr}, \mathrm{Cu}, \mathrm{Pb}$ and $\mathrm{Zn}$ in sediments from Jianhu Lake compared with other sediments (mg/kg).

\begin{tabular}{|c|c|c|c|c|c|c|c|c|c|c|}
\hline & \multicolumn{2}{|c|}{$\mathrm{Cd}$} & \multicolumn{2}{|c|}{$\mathrm{Cr}$} & \multicolumn{2}{|c|}{$\mathrm{Cu}$} & \multicolumn{2}{|c|}{$\mathrm{Pb}$} & \multicolumn{2}{|c|}{$\mathrm{Zn}$} \\
\hline & Surface & Core & Surface & Core & Surface & Core & Surface & Core & Surface & Core \\
\hline East of Jianhu lake & 0.42 & 0.42 & 144.01 & 171.06 & 50.32 & 57.08 & 45.68 & 34.07 & 178.97 & 189.34 \\
\hline Middle of Jianhu lake & 0.31 & 0.35 & 185.49 & 218.78 & 45.13 & 55.46 & 37.63 & 34.53 & 106.38 & 145.66 \\
\hline West of Jianhu lake & 0.29 & 0.33 & 122.97 & 230.64 & 33.46 & 45.02 & 37.52 & 46.24 & 105.89 & 137.27 \\
\hline Entirety of Jianhu lake & 0.33 & 0.36 & 154.28 & 210.80 & 42.53 & 52.38 & 39.61 & 38.32 & 124.36 & 153.78 \\
\hline National aquatic sediments in China & \multicolumn{2}{|c|}{0.18} & \multicolumn{2}{|c|}{61.00} & \multicolumn{2}{|c|}{23.00} & \multicolumn{2}{|c|}{27.00} & \multicolumn{2}{|c|}{71.00} \\
\hline South aquatic sediments in China & \multicolumn{2}{|c|}{0.23} & \multicolumn{2}{|c|}{57.00} & \multicolumn{2}{|c|}{25.00} & \multicolumn{2}{|c|}{32.30} & \multicolumn{2}{|c|}{81.00} \\
\hline $\begin{array}{c}\text { Soil background value of Yunnan } \\
\text { Province }\end{array}$ & \multicolumn{2}{|c|}{0.22} & \multicolumn{2}{|c|}{65.20} & \multicolumn{2}{|c|}{46.30} & \multicolumn{2}{|c|}{40.60} & \multicolumn{2}{|c|}{89.70} \\
\hline
\end{tabular}

Notes: the results of the average concentrations in national aquatic sediments and south aquatic sediments in China were from the study by Ren et al. and Cheng et al [36-37], respectively. The soil background value in Yunnan Province was from the survey by the China National Environmental Monitoring Center [27].

\section{Heavy Metal Concentrations in Core Sediments}

The concentrations of $\mathrm{Cd}, \mathrm{Cr}, \mathrm{Cu}, \mathrm{Pb}$ and $\mathrm{Zn}$ in the core sediments of Jianhu Lake were $0.513 \pm 0.442$, $228 \pm 175,89.9 \pm 74.6,74.9 \pm 65.7$, and $209 \pm 172 \mathrm{mg} / \mathrm{kg}$, respectively. It can also be seen from Table 3 that the concentrations of different heavy metal elements varied greatly in core sediments in different areas of the lake. The average concentrations of $\mathrm{Cd}, \mathrm{Cu}$ and $\mathrm{Zn}$ followed the order of west $>$ middle $>$ east, and the average concentrations of $\mathrm{Cr}$ and $\mathrm{Pb}$ were in the order of east $>$ middle $>$ west. The average concentrations of all heavy metal elements in core sediments exceeded the mean values in national aquatic sediments and south aquatic sediments in China. $\mathrm{Pb}$ was close to the soil background value in Yunnan Province, and the average concentrations of other elements were higher than the soil background value in the province.

The vertical spatial distribution of heavy metals in core sediments from Jianhu is shown in Fig. 3. The average coefficients of variation of $\mathrm{Cd}, \mathrm{Cr}, \mathrm{Cu}$, $\mathrm{Pb}$ and $\mathrm{Zn}$ were $36 \%, 29 \%, 35 \%, 49 \%$ and $38 \%$, respectively. The highest concentrations of $\mathrm{Cd}, \mathrm{Cr}$ and $\mathrm{Pb}$ appeared at sampling point number 10, while the highest concentrations of $\mathrm{Cu}$ and $\mathrm{Zn}$ appeared at sampling points 8 and 1 . The average concentrations of $\mathrm{Cd}, \mathrm{Cr}, \mathrm{Cu}, \mathrm{Pb}$, and $\mathrm{Zn}$ in the bottom layer $(70-75 \mathrm{~cm})$ were $1.24,1.33,1.41,1.23$, and 1.26 times that in the surface layer $(0-5 \mathrm{~cm})$. In addition, the highest average concentrations of $\mathrm{Cd}, \mathrm{Cu}$ and $\mathrm{Zn}$ appeared in the 60-65 cm layer, and the highest average concentrations of $\mathrm{Cr}$ and $\mathrm{Pb}$ appeared in the $45-50 \mathrm{~cm}$ and $70-75 \mathrm{~cm}$ layers, respectively. In general, the total concentration of heavy metals in surface sediments was lower than that in the bottom sediments from Jianhu Lake, and the concentrations of some heavy metals tended to decrease from the bottom layer to the surface layer.

\section{Pollution and Ecological Risk Assessment}

The geoaccumulation index of heavy metals in the sediments from Jianhu Lake is shown in Fig. 4. The average $I_{\text {geo }}$ of $\mathrm{Cd}, \mathrm{Cr}, \mathrm{Cu}, \mathrm{Pb}$ and $\mathrm{Zn}$ were -0.27 , $0.47,-0.90,-1.08$, and -0.28 in surface sediments, respectively. In surface sediments, the degree of $\mathrm{Cd}$, $\mathrm{Pb}$ and $\mathrm{Zn}$ pollution followed the order of west $>$ midde $>$ east, and the degree of $\mathrm{Cr}$ and $\mathrm{Cu}$ pollution was middle>west>east. The average $I_{\text {geo }}$ in core sediments were $0.00,0.96,-0.56,-1.02$, and 0.01 , respectively. In surface sediments, the degree of $\mathrm{Cd}, \mathrm{Cr}$, and $\mathrm{Zn}$ pollution followed the order of west $>$ middle $>$ east, the degree of $\mathrm{Cu}$ pollution was middle $>$ west $>$ east, and the degree of $\mathrm{Pb}$ pollution was east $>$ middle $>$ west. The degree of heavy metal pollution in Jianhu sediments was markedly different, and the degree of $\mathrm{Pb}$ pollution was lowest and $\mathrm{Cr}$ pollution was greatest. The $I_{\text {geo }}$ of $\mathrm{Cr}$ at the 12 sampling points in surface and core sediments was greater than 1 at $42 \%$, which demonstrated very slight pollution, while $25 \%$ and $58 \%$ of $I_{\text {geo }}$ were between 0 and 1, respectively, indicating a low pollution level, and the remaining sites were clean. Furthermore, the average $I_{\text {geo }}$ of $\mathrm{Cr}$ in the surface $(0.47)$ and core (0.96) sediments of Jianhu all exceeded that of Yunnan Provin ce (0.19) in the study by Xu et al. [17].

The potential ecological risk assessment of heavy metals in sediments from Jianhu is shown in Fig. 5. The average $E_{r}^{i}$ of $\mathrm{Cd}, \mathrm{Cr}, \mathrm{Cu}, \mathrm{Pb}$ and $\mathrm{Zn}$ were $45.59,4.73$, $4.59,4.88$ and 1.39 in surface sediments, respectively. In surface sediments from Jianhu, $33 \%$ of the 12 sampling points had an RI of more than 80 , which is a high ecological risk level, and $25 \%$ had an RI between 40 and 80, which is a moderate ecological risk level, and the remaining sampling sites had a low ecological risk level. The average $E_{r}^{i}$ of $\mathrm{Cd}, \mathrm{Cr}, \mathrm{Cu}, \mathrm{Pb}$ and $\mathrm{Zn}$ in core sediments were 49.81, 6.47, 5.66, 4.72 and 1.71, respectively. In core sediments from Jianhu Lake, 25\% of the 12 sampling points had an RI more than 80 , 

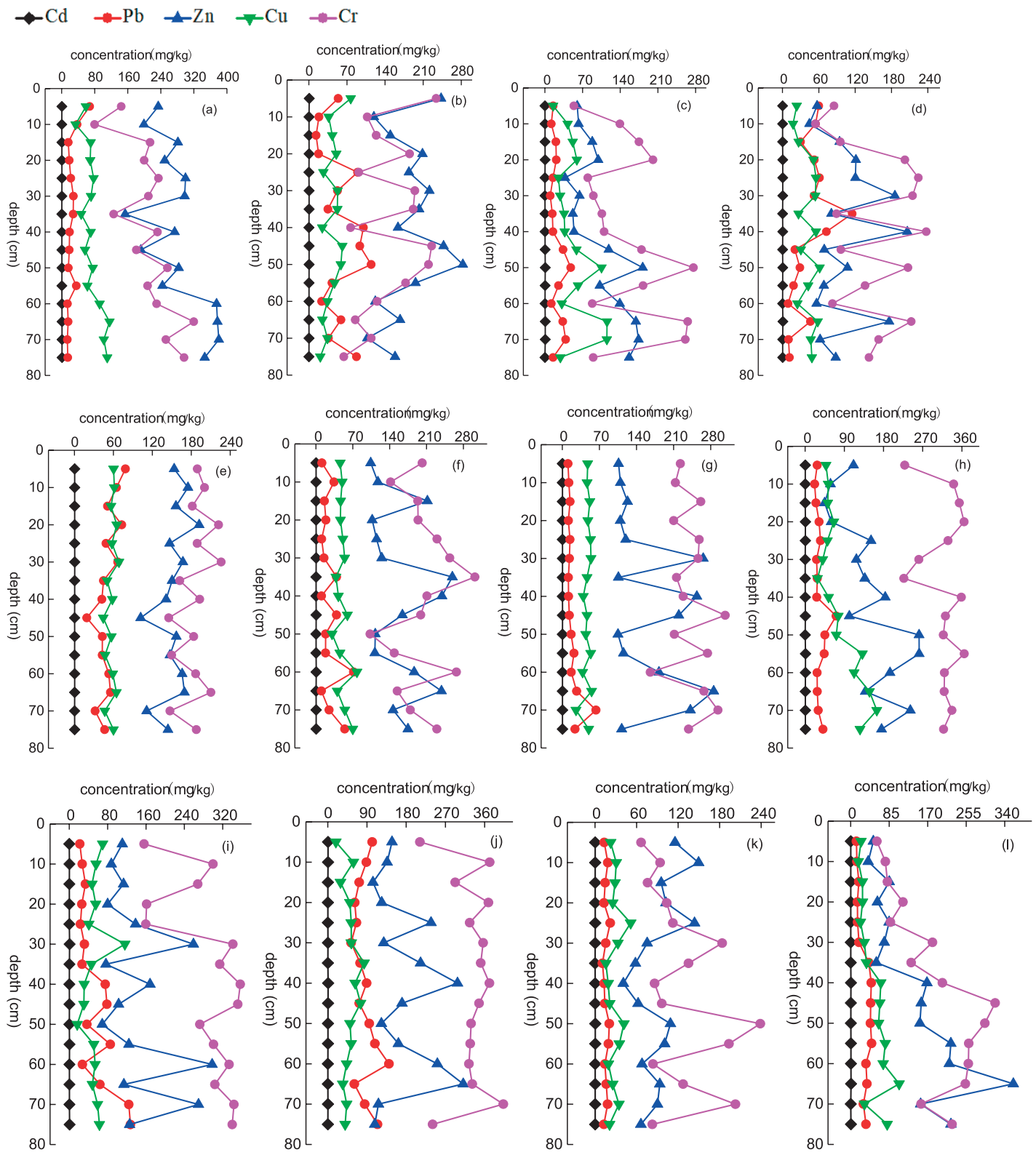

Fig. 3. Vertical distribution of heavy metals in Jianhu Lake core sediments (a to 1 show the sampling points 1 to 12).

which is a high ecological risk level, and $67 \%$ had an RI between 40 and 80 , which is a moderate ecological risk level, and the remaining sampling sites had a low ecological risk level. The average $E_{r}{ }^{i}$ of $\mathrm{Cd}$ in surface and core sediments exceeded 30 , which is a moderate risk, while the average $E_{r}{ }^{i}$ of $\mathrm{Cr}$ in the surface (4.73) and core (6.47) sediments exceeded that of Yunnan Province (3.40) in the study by $\mathrm{Xu}$ et al. [17]. The RI showed the order of west $>$ middle $>$ east in Jianhu Lake, and indicated that $\mathrm{Cd}$ contributed the greatest risk and $\mathrm{Zn}$ the lowest risk.

\section{Release Contribution}

The release contribution of heavy metals in Jianhu core sediments is shown in Table 4. At the 12 sampling points, the average short-term release contributions of
$\mathrm{Cd}, \mathrm{Cr}, \mathrm{Cu}, \mathrm{Pb}$, and $\mathrm{Zn}$ were $67 \%, 42 \%, 50 \%, 58 \%$, and $58 \%$, and the average long-term release contributions were $42 \%, 17 \%, 33 \%, 42 \%$, and $33 \%$, respectively, and mainly were released. The average short- and longterm heavy metal release contributions were $55 \%$ and $33 \%$, which equal the release status at the 12 sampling points, respectively, indicating that heavy metals in Jianhu sediments were released for a short time and stagnated for a long time. Due to the large difference in vertical spatial distribution characteristics of heavy metals in the sediments of Jianhu, and the difference in release contribution of the western, middle and eastern sections of the lake (which was also large), the overall order was west $>$ middle $>$ east. Moreover, the short-term release contribution of $\mathrm{Pb}$ and $\mathrm{Zn}$ was large, and the short-term and long-term release contributions of $\mathrm{Cr}$ were small. The release contribution of heavy metals 

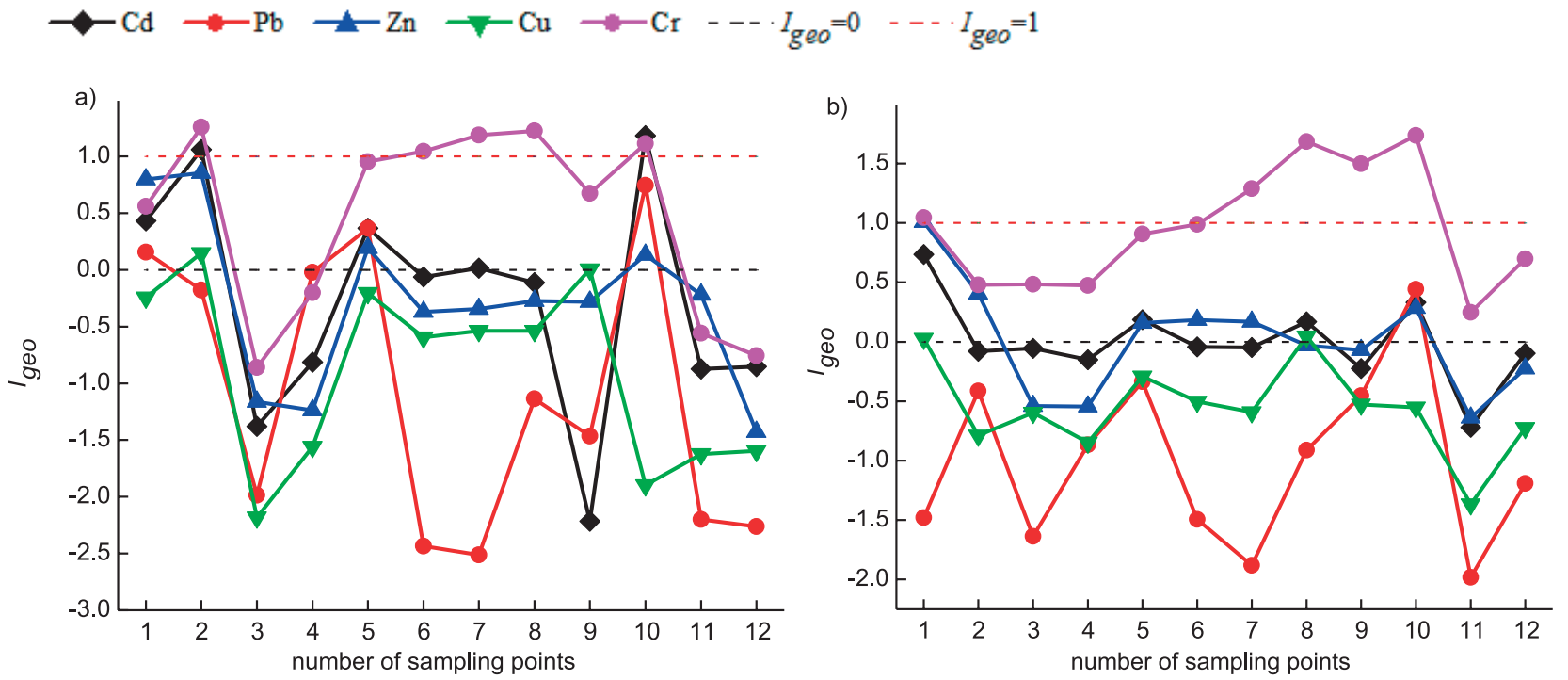

Fig. 4. Geoaccumulation index of heavy metals in surface a) and core b) sediments from Jianhu Lake.
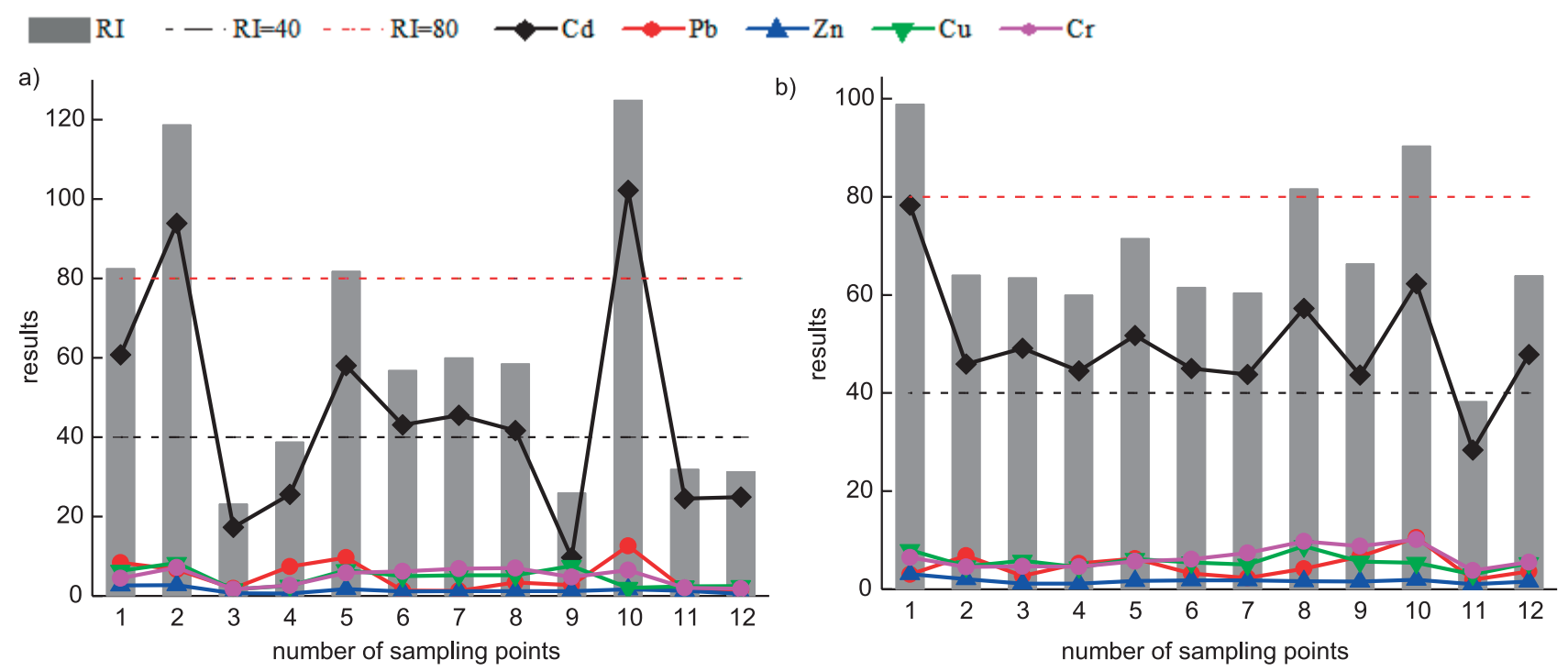

Fig. 5. Potential ecological risk index of heavy metals in surface a) and core b) sediments from Jianhu Lake.

varied considerably due to uncertainties in the sediment chronologies, particularly for heavy metals that have large variability in sediment [38].

\section{Discussion}

\section{Concentrations of Heavy Metals in Surface} and Core Sediments

Heavy metal pollution in lakes is mainly concentrated in the sediments and is transformed between the solid and liquid phases through the exchange reaction in the interface of water-sediment [39]. In addition, the most frequent exchange of substances and energy is between water and sediment in surface sediments [40]. The results of the comparison with average concentrations in national aquatic sediments, south aquatic sediments in China and the soil background value in Yunnan Province showed that there was different enrichment of heavy metals in surface sediments of Jianhu Lake. The differences in the concentrations between $\mathrm{Cu}, \mathrm{Pb}$ and soil background value in Yunnan Province were small, indicating that these elements were mainly affected by regional geological background values, and human activities had little interference in these elements. Table 5 shows that there were significant positive correlations between $\mathrm{Cd}, \mathrm{Cr}, \mathrm{Cu}$, and $\mathrm{Zn}$ in Jianhu surface sediments, indicating that they had the same source of contamination or that the heavy metals had a certain relationship, and this is in agreement with the findings of Khaled et al. [22]. The concentrations of the 
Table 4. Release contributions of heavy metals in core sediments from Jianhu Lake (\%).

\begin{tabular}{|c|c|c|c|c|c|c|c|c|c|c|}
\hline \multirow{2}{*}{ Sampling point } & \multicolumn{3}{|c|}{$\mathrm{Cd}$} & \multicolumn{2}{c|}{$\mathrm{Cr}$} & \multicolumn{3}{c|}{$\mathrm{Cu}$} & \multicolumn{2}{c|}{$\mathrm{Zn}$} \\
\cline { 2 - 13 } & $V_{1}$ & $V_{2}$ & $V_{1}$ & $V_{2}$ & $V_{1}$ & $V_{2}$ & $V_{1}$ & $V_{2}$ & $V_{1}$ & $V_{2}$ \\
\hline 1 & 0.12 & -0.11 & 41.70 & -41.15 & 16.18 & -13.96 & 19.62 & 14.35 & 22.37 & -30.44 \\
\hline 2 & 0.12 & 0.15 & 38.80 & 49.28 & 12.43 & 16.21 & 10.80 & -9.77 & 37.85 & 24.59 \\
\hline 3 & -0.15 & -0.06 & -71.92 & -24.68 & -22.71 & -9.23 & 2.94 & 0.08 & -2.28 & -65.96 \\
\hline 4 & 0.08 & -0.07 & 55.92 & -35.68 & 11.30 & -15.40 & 9.69 & 29.84 & 23.02 & -19.01 \\
\hline 5 & 0.04 & 0.07 & -23.56 & 3.36 & -2.34 & 0.41 & 29.05 & 74.06 & -45.00 & 22.10 \\
\hline 6 & 0.01 & -0.09 & 59.73 & -16.71 & -3.73 & -14.47 & -22.98 & -26.10 & -13.56 & -42.63 \\
\hline 7 & -0.02 & 0.03 & 59.24 & -42.34 & 6.66 & -5.13 & -10.44 & -36.09 & -23.68 & -16.41 \\
\hline 8 & 0.03 & -0.13 & -63.61 & -36.40 & -3.03 & -31.83 & 3.35 & -5.42 & 29.98 & -26.22 \\
\hline 9 & -0.11 & -0.18 & -77.51 & -58.95 & 7.36 & 2.17 & -2.71 & -33.84 & 12.30 & -4.86 \\
\hline 10 & 0.03 & 0.45 & -71.20 & -28.50 & -17.86 & -20.74 & 5.96 & -11.85 & 4.96 & 38.46 \\
\hline 11 & -0.08 & 0.03 & -36.73 & -24.17 & -10.70 & 2.26 & -7.08 & 0.64 & -45.41 & 72.89 \\
\hline 12 & 0.12 & -0.08 & -50.07 & -39.88 & 16.50 & -13.85 & -2.89 & -5.06 & 30.42 & -41.13 \\
\hline
\end{tabular}

Notes: $V_{1}$ and $V_{2}$ represent short-term release contribution and long-term release contribution, respectively

five heavy metals in surface sediments were relatively high in the western section of the lake, as shown in Figs 1 and 2, and this indicated that the Xinshui and Yongfeng rivers were the main sources of heavy metal pollution. On the one hand, there was a lead-zinc heap upstream of the Xinshui, and the heavy metals in the mine slag entered Jianhu Lake by river transportation or soil infiltration [41], and settled near the estuary due to the decrease in water hydrodynamics at the estuary. On the other hand, the Yongfeng River was the main polluted river in Jiangchuan County, and municipal sewage increased heavy metal concentrations in the lake [17], while the quality of overlying water was closely related to sediments and increased heavy metal concentrations in the estuary sediments. In addition, the concentrations of $\mathrm{Cd}(0.08 \mathrm{mg} / \mathrm{L}), \mathrm{Pb}(0.02 \mathrm{mg} / \mathrm{L})$, and $\mathrm{Zn}(0.01 \mathrm{mg} / \mathrm{L})$ in water from the Yonfeng are higher than other tributaries according to the information provided by the Dali Jianhu Lake Wetland Provincial Nature Reserve Management and Conservation Bureau. The concentrations of $\mathrm{Cd}$ and $\mathrm{Pb}$ were high in some parts of the eastern area of Jianhu Lake as this section is close to a rural residential area, and domestic sewage and garbage are directly discharged into the lake through small ditches. This section is also near a farming region, and phosphate fertilizer is used during local agricultural cultivation. Furthermore, phosphate fertilizer is mainly derived from apatite, and most or all $\mathrm{Cd}$ in apatite in the phosphate fertilizer [42] caused the accumulation of $\mathrm{Cd}$ in that area. The concentration of $\mathrm{Cr}$ was high in the Shihe River estuary, which was due to the Shihe River that flows through Shihe Village. There are a large number of woodcarving industries in Shihe Village. The use of wood preservatives increased the content of $\mathrm{Cr}$ in the soil and soil exudates [43], and are imported into Jianhu Lake from the river. In addition, the Jinlong River was the main contaminated river due to pollution from agriculture mostly in Jianchuan County; however, the heavy metal concentrations in sediments nearby were low in the Jinlong River estuary as the sediments had been excavated in the first half of 2016, indicating that excavation can effectively remove heavy metal pollutants and reduce the concentrations of heavy metals in sediments, and this is similar to the results by Chen et al. [21].

Sediments are carriers in the lake, and continuously receive most of the pollutants from the basin. The concentrations of heavy metals in a particular layer of sediment can show the loss intensity caused by natural and human activities in the basin during this period [44]. Significant correlations were also observed between $\mathrm{Cd}, \mathrm{Cr}, \mathrm{Cu}$ and $\mathrm{Zn}$ in core sediments of Jianhu Lake, which further indicated that the sources of pollution have commonality. Natural and human activities are distinctive in different areas and different periods of Jianhu Lake; therefore, the vertical distribution of heavy metals varied greatly in some areas. In addition, the vertical distribution characteristics of heavy metals in sediments are not only affected by pollution sources and geological background, but also by factors such as aquatic plants, oxidizable organic carbon, chlorides, electrical conductivity and grain size [45], and the large differences in vertical distribution characteristics of heavy metals in sediments from Jianhu Lake may also be related to these factors. Some studies have suggested that heavy metals in sediments are mainly concentrated in the surface layer, and it is possible to transfer to the lower layer only when the surface layer 
Table 5. Correlation coefficients of heavy metals in Jianhu Lake sediments.

\begin{tabular}{|c|c|c|c|c|c|c|c|c|c|c|}
\hline \multirow{2}{*}{} & \multicolumn{4}{|c|}{ Surface sediments } & \multicolumn{5}{c|}{ Core sediments } \\
\cline { 2 - 12 } & $\mathrm{Cd}$ & $\mathrm{Cr}$ & $\mathrm{Cu}$ & $\mathrm{Pb}$ & $\mathrm{Zn}$ & $\mathrm{Cd}$ & $\mathrm{Cr}$ & $\mathrm{Cu}$ & $\mathrm{Pb}$ & $\mathrm{Zn}$ \\
\hline $\mathrm{Cd}$ & 1 & & & & & 1 & & & & \\
\hline $\mathrm{Cr}$ & $0.614^{*}$ & 1 & & & & 0.501 & 1 & & & \\
\hline $\mathrm{Cu}$ & 0.217 & $0.705^{*}$ & 1 & & & $0.852^{* *}$ & $0.646^{*}$ & 1 & & \\
\hline $\mathrm{Pb}$ & 0.560 & 0.347 & 0.158 & 1 & & 0.324 & 0.448 & 0.213 & 1 & \\
\hline $\mathrm{Zn}$ & $0.655^{*}$ & $0.684^{*}$ & $0.656^{*}$ & 0.516 & 1 & $0.794^{* *}$ & 0.440 & $0.641^{*}$ & 0.253 & 1 \\
\hline
\end{tabular}

Note: ${ }^{*}$ Correlation is significant at the 0.05 level; ${ }^{* *}$ Correlation is significant at the 0.01 level.

reaches saturation [46-47]. However, the heavy metal concentrations in Jianhu sediments were higher in the bottom layer than in the surface layer, indicating that heavy metal pollution is decreasing year by year in the lake, which is related to governmental protection and prevention measures, such as sediment dredging, plant harvesting, education propaganda and so on. The order of distribution was different from those in marine and coastal sediments [32, 47], and this may be attributed to complex reactions such as adsorption, precipitation and redox changes in the sediments [48].

\section{Ecological Assessment}

The $I_{g e o}$ and potential ecological risk of heavy metals in sediments in the western section was higher than that in other areas of Jianhu Lake, and this was related to the greater input of pollutants from the Yongfeng River and the serious loss of lead-zinc mining upstream of the Xinshui River. Human activities increased the accumulation of heavy metals in the sediments of the lake. Urban development, residential life, industrial activities and agricultural cultivation around Jianhu may increase heavy metal pollution in sediments. The most effective way to reduce heavy metal pollution in lakes is efficient control of pollution sources and strict enforcement of environmental regulations - especially wastewater discharge [17]. The $I_{g e o}$ and potential ecological risk of heavy metals in sediments in the excavation area were relatively low, indicating that the digging of sediments can effectively reduce the ecological risk and degree of heavy metal pollution, and is an effective measure for controlling the heavy metal pollution of sediments. Jianhu Lake is rich in biodiversity and plants, and some of the heavy metals in plants and animals can endanger human health through the food chain [43]. The pollution and risk degree for $\mathrm{Cd}$ are all relatively high according the assessment methods of geoaccumulation index and potential ecological risk index. Therefore, we consider that $\mathrm{Cd}$ was at a dangerous level. To be more convincing, the results obtained in our study are similar to the reports for freshwater lake sediments in China [17]. Cd is a carcinogen in humans, which can cause damage to the kidneys after enrichment in the human body, and can also cause acute bone deformation, while $\mathrm{Cr}$ poisoning can cause digestive disorders, convulsions and so on [43].

The release contribution of heavy metals in sediments from Jianhu Lake was very different mainly due to the large difference in vertical spatial distribution of the heavy metals. With the large variability in release contribution of heavy metal, we recommend that future studies account for the uncertainties associated with the sediment chronology because of the similarity to the research by Lintern et al. [38]. The release contributions of $\mathrm{Pb}$ and $\mathrm{Zn}$ were large, and $\mathrm{Pb}$ and $\mathrm{Zn}$ are harmful to humans and animals. Sludge, livestock manure, and automobile exhaust are all sources of $\mathrm{Pb}$ and $\mathrm{Zn}$ pollution [43]. Jianhu Lake is close to National Highway 214 , and the sludge, livestock manure and automobile exhaust from residential areas and the highway may increase the content of $\mathrm{Pb}$ and $\mathrm{Zn}$ in sediments of Jianhu Lake. These heavy metals will be released again when they reach saturation in sediments, and will then pollute water and the ecological environment. Heavy metals in Jianhu sediments were released for a short time and stagnated for a long time, indicating that pollution needs to be processed in time. In addition, restoring ecosystems along the lakeshore can effectively intercept pollutants and prevent their migration [17].

\section{Conclusions}

Jianhu Lake is a small shallow lake in the plateau section of Yunnan Province, China. For each heavy metal measured, the spatial distribution characteristics in surface and core sediments were different, and the concentrations of each metal also varied greatly. The overall heavy metal concentrations were in the order of west $>$ middle>east, and the concentrations in the bottom layer $(70-75 \mathrm{~cm})$ were higher than those in the surface layer $(0-5 \mathrm{~cm})$, and were mainly influenced by factors such as human activities and pollution source discharge. The average concentrations of heavy metals in surface and core sediments from Jianhu Lake were all higher than those in national aquatic sediments 
and south aquatic sediments in China, and there were significant positive correlations between $\mathrm{Cd}, \mathrm{Cr}, \mathrm{Cu}$ and $\mathrm{Zn}$. The ecological risks and degree of pollution in surface sediments of Jianhu Lake showed the following trend: $\mathrm{Cd}>\mathrm{Pb}>\mathrm{Cr}>\mathrm{Cu}>\mathrm{Zn}$ and $\mathrm{Cr}>\mathrm{Cd}>\mathrm{Zn}>\mathrm{Cu}>\mathrm{Pb}$, respectively. The ecological risks and degree of pollution in core sediments of Jianhu lake showed the following trend: $\mathrm{Cd}>\mathrm{Cr}>\mathrm{Cu}>\mathrm{Pb}>\mathrm{Zn}$ and $\mathrm{Cr}>\mathrm{Zn}>\mathrm{Cd}>\mathrm{Cu}>\mathrm{Pb}$, respectively. In the short-term, most heavy metals in the sediments of Jianhu Lake had the potential for release, while in the long-term, they had the potential for retention.

\section{Acknowledgements}

We thank International Science Editing for editing this manuscript and the Dali Jianhu Lake Wetland Provincial Nature Reserve Management and Conservation Bureau for providing the heavy metal concentrations of tributaries. This study was supported by the Joint Agricultural Projects of Yunnan Province (Grant No. 2017FG001-018).

\section{Conflict of Interest}

The authors declare no conflict of interest.

\section{References}

1. MYERS N., MITTERMEIER R.A., MITTERMEIER C.G., FONSECA G.A.B.D., KENT J. Biodiversity hotspots for conservation priorities. Nature, 403, 853, 2000.

2. ZHANG Y.N., ZHANG Z.M., GENG Y.P., OU X.K., PENG S.J., WANG W.L., FENG X., GUO J.W. Priority plant communities for conservation in Northwest Yunnan. Biodiversity Science, 21 (3), 296, 2013. (In Chinese)

3. RAMTEKE S., PATEL K.S., NAYAK, YOGITA, JAISWAL N.K., JAIN V.K., BORGESE L., GIANONCELLI A., BONTEMPI E. Contamination of heavy metals and nutrients in sediment, sludge and sewage of India. International Journal of Geosciences, 6, 1179, 2015.

4. KUCUK Y.K., TOPCU A. Ecological risk assessment and seasonal-spatial distribution of trace elements in the surface sediment of Trabzon Harbour, Turkey. Open Journal of Ecology, 7, 348, 2017.

5. EMMANUEL E., SOMBO T., UGWANYI J. Assessment of heavy metals concentration in shore sediments from the bank of River Benue, North-Central Nigeria. Journal of Geoscience and Environment protection, 6, 35, 2018.

6. FANG H., XU Y., YE Z., ZHANG Z., PAN S., DENG L., LUO Z., CHEN S. Impact of urbanization on nutrients and heavy metal pollution of Napahai Wetland, ShangriLa County, China [J]. International Journal of Sustainable Development \& World Ecology, 22 (2), 117, 2015.

7. YU Z.Z., LIU E.F., ZHANG E.L., LIU Q., SHEN J., WANG R., LI Y.L. Spatio-temporal variations, contamination and potential ecological risk of heavy metals in the sediments of Chenghai Lake. Environmental Science, 38 (10), 4169, 2017 [In Chinese].
8. DUAN Z.B., CAI X.F., WANG J., AN J.P. Heavy metal pollution of sediments of plateau lakes in China. Environmental Science \& Technology, 40 (S1), 293, 2017 [In Chinese].

9. SEKABIRA K., ORYEMORIGA H., BASAMBA T.A., MUTUMBA G., KAKUDIDI E. Assessment of heavy metal pollution in the Urban Stream sediments and its tributaries. International Journal of Environmental Science \& Technology, 7, 435, 2010.

10. NNAJI A.O., DURU P.N. An insight into the role of urbanization in the pollution of Nworie River in OwerriImo State. Proceeding of the A.N.A. 49th Conference: University of Abuja, Abuja, 2006.

11. XIAO D.D., SHI Z.T., SU B., FENG Z.B. Spatial distribution and pollution assessment of heavy metals in surface sediment of Baoxiang River, Dianchi Lake. Environmental Chemistry, 36 (12), 2719, 2017 [In Chinese].

12. ZHU X.H., LYU S.S., ZHANG P.P., CHEN X.G., WU D.D., YE Y. Heavy metal contamination in the lacustrine sediment of a plateau lake: influences of groundwater and anthropogenic pollution. Environmental Earth Sciences, 75 (2), 98, 2016.

13. SONG F.F., HU X.Z., JIN X.C. Analysis of lake management strategies of different types of lakes abroad and enlightenments for China. Journal of Environmental Engineering Technology, 3 (2), 156, 2013 [In Chinese].

14. HU Y.L., ZHENG W. Research on sustainable development in plateau lake basins. Ecological Environment, (3), 168, 2011 [In Chinese].

15. BÁRCENA J.F., CLARAMUNT I., GARCÍA-ALBA J., PÉREZ M.L. A method to assess the evolution and recovery of heavy metal pollution in estuarine sediments: Past history, present situation and future perspectives. Marine Pollution Bulletin, 124 (1), 421, 2017.

16. LONG Y.Z., DAI T.G., CHI G.X., YANG L. Assessment of heavy metals in sediment cores from Xiangjiang River, Chang-Zhu-Tan region, Hunan Province, China. Journal of Central South University, 19, 2634, 2012.

17. XU Y.F., WU Y., HAN J.G., LI P.P. The current status of heavy metal in lake sediments from China: Pollution and ecological risk assessment. Ecology and Evolution, 7 (14), 5454, 2017.

18. HUPFER M., LEWANDOWSKI J. Retention and early diagenetic transformation of phosphorus in Lake Arendsee (Germany) - consequences for management strategies. Archiv für Hydrobiologie, 164 (2), 143, 2005.

19. MADRID L., DIAZ-BARRIENTOS E., MADRID F. Distribution of heavy metal contents of urban soils in parks of Seville. Chemosphere, 49, 1301, 2002.

20. CHEN H.Y., TENG Y.G., LU S.J., WANG Y.Y., WANG J.S. Contamination features and health risk of soil heavy metals in China. Science of the Total Environment, 512513, 143, 2015.

21. CHEN M.S., DING S.M., GAO S.S., FU Z., TANG W.Y., WU Y.X., GONG M.D., WANG D., WANG Y. Efficacy of dredging engineering as a means to remove heavy metals from lake sediments. Science of the Total Environment, 665, 181, 2019.

22. KHALED A., ABDEL-HALIM A., EL-SHERIF Z., A. MOHAMED L. Health risk assessment of some heavy metals in water and sediment at Marsa-Matrouh, Mediterranean Sea, Egypt. Journal of Environmental Protection, 8, 74, 2017.

23. SHIJI M., KAVYA P., HARIKUMAR P.S.P. Sediment quality assessment of Kavvayi Wetland in South Coast India with special reference to phosphate fractionation 
and heavy metal contamination. Journal of Environmental Protection, 6, 1308, 2015.

24. LIU X., JIANG Y., GAO J.F., YIN H.B., CAI Y.J. Pollution characteristics of heavy metals and the risk assessment for the surface sediments from Lake Chaohu and its main tributary rivers. Journal of Lake sciences, 28 (3), 502, 2016 [In Chinese].

25. ZHU L., LIU J., XU S., XIE Z. Deposition behavior, risk assessment and source identification of heavy metals in reservoir sediments of Northeast China. Ecotoxicology and Environmental Safety, 142, 454, 2017.

26. HARIKRISHNANA N., RAVISANKARA R., CHANDRASEKARANB A., GANDHI M., KANAGASABAPATHY K.V., PRASAD M.V.R., SATAPATHY K.K. Assessment of heavy metal contamination in marine sediments of east coast of Tamil Nadu affected by different pollution sources. Marine Pollution Bulletin, 121 (1-2), 418, 2017.

27. CHINA NATIONAL ENVIRONMENTAL MONITORING CENTER (CNEMC). Chinese Soil Element Background Value, 2 ${ }^{\text {nd }}$ Edition. China Environmental Science Press: Beijing, China, 334-379, 1990 [In Chinese].

28. LI X.M., ZHAO S.M., WANG D.W., LI Z.Y., LI S.G., PAN X.J. Study on the pollution characteristics of heavy metals in surface sediments of Dianchi Lake. Earth and Environment, 41 (6), 647, 2013 [In Chinese].

29. HAKANSON L. An ecological risk index for aquatic pollution control. a sedimentological approach. Water Research, 14 (8), 975, 1980.

30. HOU Q., MA J.H., WANG X.Y., DUAN H.J. Bioavailability and potential ecological risk of soil heavy metals in Kindergartens, Kaifeng city. Environmental Science, 32 (6), 1764, 2011 [In Chinese].

31. DONG C.Y., ZHANG W.G., MA H.L., FENG H., LU H.H., DONG Y., YU L.Z. A magnetic record of heavy metal pollution in the Yangtze River subaqueous delta. Science of the Total Environment, 476-477, 368, 2014.

32. NAZNEEN S., SINGH S., RAJU N. Heavy metal fractionation in core sediments and potential biological risk assessment from Chilika lagoon, Odisha state, India. Quaternary International, 507, 370, 2019.

33. THEOFANIS Z., ASTRID S., LIDIA G., WOLFGANG C. Contaminants in sediments: Remobilisation and demobilization. The Science of Total Environment, 266 , 195, 2001.

34. HUANG K.M., LIN S. Consequences and implication of heavy metal spatial variations in sediments of the Keelung River drainage basin, Taiwan. Chemosphere, 53, 1113, 2003.

35. KASPAR H.F., ASHER R.A., BOYER I.C. Microbial nitrogen transformations in sediments and inorganic nitrogen fluxes across the sediment /water interface on the South Island West Coast, New Zealand. Estuarine, Coastal and Shelf Science, 21 (2), 245, 1985.
36. REN T.X., WU Z.H., QIANG R.S. Methodology for screening and verifying regional geochemical anomalies operation, $2^{\text {nd }}$ Edition. Geological Publishing House: Beijing, China, 1-138, 1998 [In Chinese].

37. CHENG Z.Z., XIE X.J., PAN H.J., YANG R., SHANG Y.T. Abundance of elements in stream in South China, Earth Science Frontiers, 18 (5), 289, 2011 [In Chinese].

38. LINTERN A., LEAHY P., DELETIC A., HEIJNIS H., ZAWADZKI A., GADD P., MCCARTHY D. Uncertainties in historical pollution data from sedimentary records from an Australian urban floodplain lake. Journal of Hydrology, 560, 560, 2018.

39. WANG M.Y., ZHANG L., QIN Y.W., LI F.S., JIA J., CAO W., ZHENG B.H. Speciation of heavy metals in sediments from Xiang River and analysis of their environmental factors. Acta Scientiae Circumstantiae, 31 (11), 2447, 2011 [In Chinese].

40. VU C.T., LIN C., SHERN C.C., YEH G., LE V.G., TRAN H.T. Contamination, ecological risk and source apportionment of heavy metals in sediments and water of a contaminated river in Taiwan. Ecological Indicators, 82, 32, 2017.

41. BÁRCENA J.F., GARCÍA A., GARCÍA J., ÁlVAREZ C., A. REVILLA J. Surface analysis of free surface and velocity to changes in river flow and tidal amplitude on a shallow mesotidal estuary: an application in Suances Estuary (Northern Spain). Journal of Hydrology, 420-421, 301, 2012.

42. DEPARTMENT OF NATURAL ECOLOGY PROTECTION, MINISTRY OF ENVIRONMENTAL PROTECTION (DNEPMEP). Soil pollution and human health, $2^{\text {nd }}$ Edition. China Environmental Publishing House: Beijing, China, 205-221, 2012 [In Chinese].

43. OLLE S., BRIAN A., JOS A.C. Essentials of Medical Geology: Impacts of the Nature Environment on Public Health (Translation by Zheng Bao Shan, Xiao Tang Fu, Li She Hong). Science Press: Beijing, China, 47-322, 2009.

44. FAN C.X., ZHANG L. Lake Taihu: principles of Sediment Pollution and Remediation, $2^{\text {nd }}$ Edition. Science Press: Beijing, China, 164, 2009 [In Chinese].

45. EL-AMIER Y.A., EL-KAWY Z.M.A., AL-MAMORY S.H. Assessment the physico-chemical characteristics of water and sediment in Rosetta Branch, Egypt. Journal of Water Resource and Protection, 7, 1075, 2015.

46. TAM N.F.Y., WONG Y.S. Retention and distribution of heavy metals in mangrove soils receiving wastewater. Environmental Pollution, 94 (3), 283, 1996.

47. CHEN Z.L., LIU P.F., XU S.Y., LIU L., YU J., YU L.Z. Spatial distribution and accumulation of heavy metals in Tidal flat sediments of Shanghai coastal zone. Science in China, 44, 197, 2001.

48. JAIN C.K., GUPTA H., CHAKRAPANI G.J. Enrichment and fractionation of heavy metals in bed sediments of River Narmada, India. Environmental Monitoring and Assessment, 141, 35, 2008. 